\title{
Pengintegrasian Motif Ibadah Pendidik Sebagai Upaya Optimalisasi Pencapaian Tujuan Pendidikan
}

\author{
Dahlan Dahlan ${ }^{1 *)} \&$ Refnadi Refnadi ${ }^{2}$ \\ ${ }^{1}$ UIN Sulthan Thaha Saifuddin \\ ${ }^{2}$ Universitas Negeri Padang \\ છ e-mail: 58dahlan@gmail.com
}

\begin{abstract}
Abstrak
Pendidikan secara praktiknya tidak terlepas dari proses pembelajaran sepanjang ayat. Konsep ini bertujuan untuk mengidentifikasi keadaan muatan motif yang ada pada diri para pelaksana pendidikan, seperti pendidik, peserta didik, terutama terkait dengan penyelenggaraan proses pembelajaran sebagai suatu ibadah. Secara implisit penyelenggaraan proses pembelajaran merupakan suatu perbuatan ibadah. Perbuatan ibadah ini dilatarbelakangi oleh motif-motif tertentu oleh pelakunya, terutama pendidik dan peserta didik yang secara langsung terlibat di dalamnya. Setiap peserta didik sudah diberikan oleh Allah seperangkat potensi (fitrah) yang harus dikembangkan seoptimal mungkin melalui pendidikan. Potensi yang diberikan itu berjumlah 99 buah, seperti yang termuat dalam Asmaul Husna yang apabila dikembangkan akan mengembangkannya menjadi berbagai potensi. Hal ini sangat bergantung kepada peran pendidik yang akan membimbing pengembangannya.
\end{abstract}

Kata Kunci: motif ibadah, pendidikan, integrasi, asmaul husna

Copyright (C) 2017 IICET (Indonesia) - All Rights Reserved

Indonesian Institute for Counseling, Education and Therapy (IICET)

\section{PENDAHULUAN}

Pendidikan merupakan suatu kegiatan pembelajaran sepanjang hayat yang bertujuan untuk mengembangkan potensi peserta didik secara optimal (Sudarsana, I. K.,2016). Pengembangan potensi tersebut bertujuan agar insan yang di didik mampu merefleksikan potensinya ke dalam perilakunya, baik perilaku kognitif, afektif, maupun psikomotor. Adapun pada ranah kognitif misalnya akan terjadi perubahan cara dan tingkat berpikir, mulai dari pengetahuan, ingatan, pemahaman hingga memiliki kemampuan dalam mengevaluasi dan mengkreasikan sesuatu (Gunawan, I., \& Palupi, A. R., 2016). Selanjutnya pada ranah afektif, terjadi perubahan sikap dan tingkah laku, mulai dari menerima nilai-nilai luhur yang berkembang menjadi internalisasi sampai meningkat menjadi pengamalan nilai-nilai sehingga merupakan bagian yang integral dari karakter atau pribadi peserta didik (Setyowati, E., 2009). Begitu pula pada ranah psikomotor, menurut Utari, R., Madya, W., \& Pusdiklat, K. N. P. K. (2011) terjadi perubahan keterampilan fisik motorik yang menyatu dengan kematangan kognitif dan afektif pada kepribadian peserta didik. Sasaran pendidikan tersebut sudah secara resmi menjadi tujuan pendidikan nasional Indonesia seperti ditetapkan pada pasal 1 ayat 1 Ketentuan Umum dan pasal 3 bab II UU. No 20 Tahun 2003 tentang Sistem Pendidikan Nasional (UUSPN).

Secara praktis fungsi pendidikan formal dan informal dapat mengungkapkan potensi-potensi tersembunyi melalui proses pembelajaran yang kondusif (Rahmawati, R. F., 2016). Setiap peserta didik adalah individu unik serta mempunyai kesiapan dan kemampuan fisik, psikis dan intelektual yang berbeda antara satu dengan lainnya, sehingga fungsi pendidikan perlu menyediakan layanan bimbingan yang sesuai dengan keberagaman individu peserta didik (individual differences) dalam mengoptimalkan potensi setiap peserta didik. 
Adapun pengoptimalan potensi peserta didik dapat ditingkatkan melalui pendidikan formal dan informal, peningkatan pendidikan formal yaitu di sekolah dan pendidikan non formal yaitu di keluarga (Indonesia, P. R.,2003). Hadits riwayat Bukhari dan Muslim, Rasulullah SAW bersabda: Setiap anak dilahirkan dalam keadaan fitrah, hingga lisannya dapat mengungkapkan kehendak dirinya, maka kedua orang tuanyalah yang menjadikannya sebagai orang Yahudi, Nasrani atau orang Majusi (HR. Bukhari dan Muslim dari Abi Hurairah). Artinya bahwa keluarga perlu memberikan pembelajaran serta keteladan agar memiliki potensi yang optimal dan tentunya harus didukung dengan pendidikan formal untuk mengembangkan nilai afektif, kognitif dan psikomotornya.

Penjabaran diatas didukung oleh Hasan Langgulung (1991) yang merekomendasikan perlunya fitrah itu dioptimalkan pengembangannya agar dapat mendekati sifat-sifat Tuhan yang berjumlah 99 buah dengan nama-nama yang indah (al-Asma al-Husna). Selain itu, Allah mengamanatkan agar manusia memanfaatkan potensi yang dimiliki agar mampu berperan sebagai khalifah di atas bumi (Masruri, H. H.,2012). Hal ini menggambarkan betapa besar dan berharganya potensi yang dianugerah-kan Allah kepada manusia. Analoginya yaitu jika manusia diletakkan di sebuah alam sekitar tanpa sumber-sumber hidup sama sekali, ia tetap akan survive.

Idealnya pendidikan di sekolah sebagai sarana dalam meningkatkan kualitas sumber daya manusia untuk membentuk generasi muda berwawasan nasional yang kuat. Sementara itu, fenomena yang ditemukan di lapangan kondisi idealnya pendidikan mulai bergeser dengan adanya indikasi bahwa pendidikan (sekolah) kurang fokus pada pengembangan fitrah peserta didik. Akibatnya menjadikan sekolah tidak mampu mewujudkan insan pendidikan yang mampu meningkatkan kualitas kehidupan Sanaky, H. A. (2008). Hal ini disebabkan oleh proses pendidikan yang kurang fokus pada pengembangan potensi peserta didik, tetapi lebih fokus pada pengajaran aspek kognitif, afektif dan psikomotor secara terpisah-pisah, belum fokus pada pengembangan dan pengintegrasian ketiga aspek melalui proses pembelajaran (Suherman, E., 2008).

Fenomena diatas bertentangan dengan tujuan dari proses pembelajaran yang dilaksanakan dalam sistem pendidikan nasional Indonesia sebagai bentuk manifestasi nyata dari usaha peningkatan kualitas manusia Indonesia (Raharjo, S. B.,2010). Manifestasi nyata dari usaha peningkatan kualitas manusia berarti bahwa kelangsungan pengembangan setiap manusia harus membentuk jalinan yang sinergis dari berbagai sumber daya yang saling mendukung, karena optimalisasi pengembangan fitrah atau potensi setiap manusia itulah yang harus menjadi subjek pendidikan agar terlahir pelaku-pelaku pembangunan yang diinginkan. Dengan perkataan lain, manusia yang bermental pembangunan yang dibutuhkan hanya akan tercipta jika fokus pendidikan diarahkan pada pengembangan kemampuan mengembangkan diri (self-development) setiap peserta didik dan secara bersama bertanggung jawab atas pembangunan bangsanya.

Sebaliknya, jiwa pembangunan tersebut berpotensi tidak akan terwujud jika pendidikan terbatas pada pengembangan ranah kognitif peserta didik saja, yaitu pada tingkat ranah kognitif paling rendah, hanya sekedar mengetahui (to know) saja, belum sampai pada tingkat to understand, dan to apply, apalagi pada tingkat analisis, sintesis, evaluasi dan kreasi. Akibatnya pengembangan semua potensi peserta didik tidak pernah optimal yang akibatnya upaya untuk membuat mereka sebagai orang yang terdidik dan fungsional di masyarakat sangat sukar diwujudkan. Hal demikian berarti bahwa kebutuhan sumber daya manusia yang berkualitas seringkali masih diartikan secara terbatas. Faktor penyebabnya yaitu pendidikan masih tertuju pada tingkat keterampilan dan kemampuan intelektual saja, sedangkan aspek afektif seperti moralitas, kejujuran, khususnya karakter insan yang dididik belum mendapat menjadi fokus utama dalam pendidikan (Sudarsana, I. K.,2016).

Pendidikan pada proses pembelajaran tujuannya mengoptimalkan pengembangan potensi (fitrah) peserta didik merupakan perbuatan yang sangat mulia; sebagai ibadah yang sangat tinggi nilainya. Adapun nuansa pembelajaran telah dinukilkan oleh Allah SWT yang intinya adalah bahwa manusia diperintahkan untuk membaca atau mempelajari ayat-ayat Allah. Hal demikian berkaitan dengan perintah dari Nabi Muhammad SAW bahkan mengajarkan manusia belajar sejauh mungkin, seperti kata pepatah yang mengatakan "tuntutlah ilmu sampai ke Negeri Cina" (Padmowihardjo, S.,2014; Rochmat, S. (2002); Shomad, A., 2004; Wahyuddin, W., 2017. Pendidik yang telah memberikan nilai hasil pembelajaran terhadap peserta didik sehingga menjadikannya memahami dan mengerti akan ilmu yang dipelajari. Hal ini menjadi amal jariyah tersendiri yang membuahkan pahala apabila seseorang (pendidik) berhasil membelajarkan seseorang atau sekelompok individu yang kemudian diamalkannya untuk kebaikan. Demikianlah, betapa mulianya kegiatan pembelajaran 
sebagai ibadah. Apabila pendidikan sebagai ibadah ini diilhami oleh setiap pendidik maupun insan yang di didik maka akan tercapainya pendidikan untuk kemaslahatan umat manusia.

\section{HASIL DAN PEMBAHASAN \\ Pekerjaan Mendidik/Mengajar Sebagai Ibadah}

Mendidik berarti memelihara dan memberi latihan (ajaran, tuntunan, pimpinan) mengenai akhlak dan kecerdasan pikiran (Depdikbud, 1999; Meria, A.,2012). Hal demikian selajan dengan tugas pendidik dalam proses pembelajaran adalah untuk memelihara, melatih, mengajar, menuntun dan memimpin peserta didik mencapai tujuan hidupnya. Secara implisit, berarti ada sesuatu yang harus dipelihara atau dilatih. "Sesuatu" itu adalah potensi (fitrah) yang sudah ada pada diri peserta didik yang sudah dibawa sejak lahir. Oleh sebab itu, pendidik bertugas mengajar, menuntun dan memimpin pengembangan potensi tersebut sesuai dengan petunjuk Allah SWT. Hal demikian sejalan dengan pendapat Hasan Langgulung (1991) dimana pengembangan fitrah melalui pendidikan disebut ibadah.

Proses pengembangan pendidikan yang disebut ibadah mestinya semua kegiatan pendidikan mengandung makna ketundukan dan kerendahan secara optimal dan komitmen tinggi yang muncul dari kecintaan, yang membuat seorang manusia menghambakan diri kepada Allah (Langgulung, H., 2001). Bentuk nyata dari kegiatan pendidikan menurut P3KP/ Pokja Pengembangan Peta Keilmuan Pendidikan (2005) adalah proses pembelajaran, bahkan ditegaskan lagi bahwa "tiada pendidikan tanpa proses pembelajaran". Selanjutnya Prayitno (2002) juga mengungkapkan kegiatan pendidikan merupakan upaya yang istimewa karena dengan pendidikan itulah manusia dipersiapkan untuk menjalani kehidupannya, dibukakan jalan untuk memperkembangkan kehidupannya, serta diarahkan dan dimungkinkan untuk mencapai tujuan kehidupannya, yaitu kebahagiaan di dunia dan di akhirat.

Berdasarkan penjabaran diatas dapat disimpulkan bahwa kegiatan pendidikan yang diwujudkan dalam bentuk proses pembelajaran penuh dengan nilai ibadah, karena pendidik dan peserta didik sedang melaksanakan suatu kewajiban mengajar dan belajar untuk memperoleh ilmu yang sangat dianjurkan oleh Allah. Hal demikian sebagaimana yang dimaksud dalam firman Allah surat al-Alaq/96:1 - 5 dan dalam sebuah hadits, Rasulullah SAW bersabda: "Menuntut ilmu lebih utama dari shalat, puasa, haji dan berjihad di jalan Allah, sehingga proses pembelajaran yang dilakukan akan bernilai ibadah. Nilai ibadah pada perilaku seseorang memiliki ciri: 1) kepatuhan dan ketaatan untuk mengagungkan Allah, 2) perbuatan baik yang diridai Allah, 3) fokus saat melakukan kewajiban, 4) diniati untuk beribadah, 5) dilakukan dengan al-Ihsan, yaitu berhati-hati serta menghadirkan kebesaran dan kemuliaan Allah ketika melakukan kewajiban dilakukan dengan keikhlasan, yaitu ketulusan hati, kejujuran dan kerelaan (Al-Nawawi, 2001; Depdikbud, 1999).

Keikhlasan seperti tersebut dalam firman Allah surat al-Baiyinah/98: 5, al-Zumar/39: 2 dan 11, alA'raf/7:29, seringkali dihubungkan dengan niat yang dipasang pada setiap amal perbuatan, sehingga keikhlasan menempati posisi yang penting dalam semua perilaku pendidikan. Selanjutnya, juga didukung Katsir, I., \& Katsir, T. S. T. I. (1984) ikhlas merupakan ruh semua amal perbuatan yang mensyaratkan agar dalam setiap aktivitas sangat bergantung kepada niat. Niat itu identik dengan motif ibadah berupa nilai rohani yang menentukan ikhlas atau tidaknya perbuatan seseorang, sesuai firman Allah QS. Al-Fatihah/1:5. Itulah sebabnya mengapa Allah SWT tidak akan menerima amal seseorang kalau tidak berdasarkan keikhlasan.

Dalam melaksanakan proses pembelajaran, nilai ibadah akan lebih konkret apabila seorang pendidik dengan penuh keikhlasan mengaplikasikan kewibawaan sebagai alat pendidikan. Artinya, semua perilaku pembelajaran yang bernilai ibadah dapat diteladani oleh peserta didik dan dapat menerapkannya dalam kehidupannya kelak. Namun hal demikian tidak terlepas dari landasan perilaku pendidik tersebut adalah yang sesuai dengan tuntunan agama, sehingga pendidik berhak atas pujian dan keteladanan akan sikapnya tersebut.

\section{Motif dan Motif Ibadah}

Beberapa ahli mengemukakan pengertian dari motif, yaitu dorongan yang menggerakkan seseorang bertingkah laku (Faizah, L. M. E., 2006; Maarif, M. S., 2003; Prayitno, 2009). Dorongan ini hidup pada diri seseorang dan setiap kali mengusik serta menggerakkan orang itu untuk melakukan sesuatu sesuai dengan apa yang terkandung di dalam dorongan itu sendiri (Usman, 1996, Kenneth, 1992, Suryabrata, 2002, Dimyati dan Mudjiono, 1999, Ulich 1961, Prayitno, 1999). Motif tersebut terdiri dari motif intrinsik dan ekstrinsik. Motif intrinsik merupakan tenaga pendorong suatu perbuatan yang dilakukan orang, sehingga 
orang itu senang dan termotivasi melakukannya secara terus menerus serta memberi energi dan motivasi berprestasi, sedangkan motif ekstrinsik merupakan dorongan seseorang untuk melakukan sesuatu dari luar, seperti ajakan, suruhan, paksaan, hadiah atau reward" (Kenneth, 1992) atau menghindari hukuman (Madsen, 1961). Prayitno (1999) mengungkapkan bahwa motif intrinsik timbul bila isi atau tema pokok tingkah laku sesuai dengan, atau berada di dalam isi atau tema pokok objek tingkah laku itu, sedangkan motif ekstrinsik dapat dijumpai apabila isi atau tema pokok tingkah laku tidak bersesuaian atau berada di luar isi atau tema pokok objeknya.

Secara konseptual ada dua jenis motif dan motivasi, yaitu intrinsik dan ekstrinsik. Namun, Prayitno (2009) menemukan motif lain yaitu motif ibadah yang dapat dikembangkan di balik tingkah laku seseorang. Artinya, selain motif intrinsik dan ekstrinsik terdapat motif lainnya. Prayitno (2009) mencontohkan dengan perilaku seorang ibu yang memberi makan seorang pengemis yang kelaparan. Motif intrinsiknya ialah agar pengemis itu terbebas dari rasa laparnya, sedangkan motif ekstrinsik mungkin si pemberi makan ingin agar dirinya dianggap sebagai dermawan yang pemurah dan baik hati. Pada perbuatan seperti ini dapat dikembangkan motif ibadah, yaitu menolong sesama manusia yang menderita sebagaimana diperintahkan oleh Allah dalam firman-Nya surat Al-Maaidah/5:2. Penafsirannya yaitu jika seseorang yang memberi makan seorang pengemis yang kelaparan dan diniati untuk beribadah serta dilaksanakan dengan penuh keikhlasan disebut perbuatannya bermotif ibadah.

Berdasarkan uraian di atas, dapat ditegaskan bahwa motif ibadah ada di dalam suatu tingkah laku apabila tingkah laku itu didasarkan atau setidak-tidaknya diwarnai oleh karakteristik untuk mengagungkan Allah, melaksanakan perintah Allah, menghindari larangan-Nya, mengharapkan rida-Nya, ikhlas karena Allah, fokus terhadap sasaran kegiatan; dan berhati-hati dalam melaksanakan kegiatan.

\section{Pendidikan \\ Manusia dan Pendidikan}

Pendidikan merupakan kegiatan khas manusia yang pada dasarnya adalah dari manusia oleh manusia dan untuk manusia. Hal demikian diindikasikan manusia sekaligus sebagai sumber, sasaran dan pelaksana pendidikan. Mengingat pentingnya kedudukan manusia, maka hal yang direkomendasikan oleh Pokja Pengembangan Peta Keilmuan Pendidikan (P3KP, 2005) dimana "Ilmu pendidikan meliputi kajian tentang manusia yang memerlukan dan dapat melaksanakan pendidikan, tujuan pendidikan, peserta didik dan pendidik, serta proses pembelajaran sebagai wujud pelaksanaan kegiatan pendidikan". Selanjutnya Pokja Pengembangan Peta Keilmuan Pendidikan (P3KP, 2005) dan Prayitno (2005) juga mengungkapkan bahwa kajian tentang hakikat manusia menjadi dasar bagi teori dan praktik pendidikan. Bahkan landasan kegiatan pendidikan semestinya berdasarkan pandangan tentang hakikat manusia.

Hakikat manusia mencerminkan harkat dan martabat manusia (HMM) yang dimaksudkan itu mengandung pengertian dasar bahwa manusia adalah makhluk yang beriman dan bertakwa kepada Tuhan Yang Maha Kuasa, makhluk yang terindah dalam kelengkapan dan bentuk penciptaannya (Surat $A l$ Tiin/95:4), makhluk yang tertinggi derajatnya (Surat Al-Mujadilah/58:11), menjadi khalifah di muka bumi (Surat Al-Baqarah/2:30), dan pemilik hak-hak asasi manusia (HAM). Supaya manusia mampu melaksanakan tugas kekhalifahan itu, Allah membekalinya dengan seperangkat potensi (fitrah) yang dapat dikembangkan secara optimal. Oleh karena itu, pendidikan harus berorientasi pada pengembangan semua potensi manusia seoptimal mungkin agar mampu memikul tanggung jawab sebagai khalifah berdasarkan jiwa pengabdian kepada Allah semata.

\section{Tujuan Pendidikan}

Menurut Suderadjat (2004) menyebutkan tujuan utama pendidikan adalah pembentukan manusia menjadi pemimpin di muka bumi sesuai amanat Allah SWT kepada manusia. Oleh sebab itu, pendidikan tidak boleh menghasilkan lulusan yang tidak menyadari statusnya sebagai hamba Allah yang harus beribadah kapada-Nya. Selain itu, pendidikan semestinya juga berorientasi ulil albab yang kaffah yaitu pendidikan bernuansa iman dan taqwa untuk menguasai ilmu pengetahuan dan teknologi agar diamalkan dalam kehidupan sehari-hari, sehingga bermanfaat bagi dirinya, keluarga, bangsa, negara dan agamanya (Suharjono, M., 2013; Asfiati, A. (2014).

Dari sisi lain, Hasan Langgulung (1991) merinci tujuan tertinggi (ultimate aim) dari pendidikan, yaitu untuk menciptakan manusia penyembah Allah dan sebagai waliy demi mencari kebahagiaan di dunia dan di 
akhirat. Berdasarkan hal demikian, tujuan pendidikan di Indonesia relevan dengan tujuan yang ingin dicapai dalam ajaran Islam. Oleh karena itu, apabila praktek pendidikan di Indonesia masih berpusat pada pengembangan aspek kognitif (content-based) saja dinilai belum tepat tetapi harus menjadikan pengetahuan sebagai kendaraan (content-vehicle) menuju pembentukan manusia yang kaffah. Manusia yang kaffah yaitu manusia Indonesia yang tidak cukup hanya sebagai muslim beriman saja, tetapi yang lebih penting dapat beramal saleh sehingga menimbulkan rahmat bagi umat manusia, dan alam pemberian Allah (rahmatan li al'alamin).

\section{Pendidik}

Menurut Prayitno (2002); P3KP (2005) memandang pendidik sebagai seseorang yang dengan sadar dapat memenuhi apa yang ingin didapatkan oleh peserta didik dalam proses pembelajaran, yaitu komponen yang aktif mengembangkan proses pembelajaran untuk memfasilitasi peserta didik agar mencapai tujuan pendidikan.

Selanjutnya, Al-Gazali (1997) merincikan sifat-sifat yang harus dimiliki seorang pendidik adalah, pendidik yaitu: 1) memperlakukan peserta didik seperti anak sendiri, 2) mengharapkan keridaan Allah dan mendekatkan diri kepada-Nya, 3) meyakinkan tujuan menuntut ilmu itu bukan untuk memperoleh kedudukan atau kebanggaan duniawi, 4) memberi teguran dengan penuh kasih sayang, 5) mendorong peserta didik mencintai semua bidang studi, 6) mendidik sesuai dengan kemampuan berpikirnya, 7) memperhatikan peserta didik yang lemah sehingga timbul kecintaannya terhadap pelajaran, dan 8) perbuatan pendidik sesuai dengan ilmu yang diajarkan. Artinya, seorang pendidik bukan hanya bertugas mengajar saja, tetapi melalui pengajaran tersebut harus menanamkan nilai-nilai pendidikan, memiliki kepribadian yang tinggi, sehingga diteladani peserta didik dan menimbulkan sifat-sifat yang positif, baik sebagai individu, pendidik, dan anggota masyarakat.

Analisis lebih jauh, terutama menyangkut unsur-unsur keilmuan pendidikan, P3KP (2005) sejalan dengan pendapat di atas Prayitno (2005), mengungkapkan bahwa kewibawaan adalah unsur keilmuan pendidikan yang merupakan salah satu dari dua pilar bangunan proses pembelajaran yang menjadi kewajiban pendidik melaksanakannya. Pilar pertama ini meliputi lima sub unsur, yaitu (a) penerimaan (adanya saling memahami dan menerima antara pendidik dan peserta didik), (b) kasih sayang dan kelembutan, (c) penguatan (reinforcement) terhadap peserta didik, (d) tindakan tegas yang mendidik (bukan hukuman) terhadap peserta didik, dan (e) keteladanan dari pendidik. Aplikasi kewibawaan ini terhadap peserta didik akan menghasilkan sentuhan mendalam (high touch) dari pendidik terhadap peserta didik, sehingga timbul suasana ing ngarso sung tulodo, ing madyo mangun karso, tut wuri handayani.

Selanjutnya, menurut Gustina, G. (2016) pilar kedua bangunan proses pembelajaran adalah apa yang disebut kewiyataan yang meliputi sub unsur kegiatan nyata pengajaran yang dilaksanakan oleh pendidik terhadap peserta didik, yaitu (a) penguasaan pendidik atas kurikulum dan materi pembelajaran, (b) metode pembelajaran, (c) alat bantu pembelajaran, (d) lingkungan pembelajaran, dan (e) menilai hasil pembelajaran. Penguasaan dan aplikasi unsur-unsur kewiyataan itu terhadap peserta didik dalam mutu yang baik yang merupakan praktek tekonologi tinggi (high tech) pendidik dalam proses pembelajaran.

\section{Peserta Didik}

Berdasarkan pasal 1 ayat (4) UU-SPN, peserta didik adalah anggota masyarakat yang berusaha mengembangkan potensi diri melalui proses pembelajaran yang tersedia pada jalur, jenjang, dan jenis pendidikan tertentu. P3KP (2005) juga menjelaskan peserta didik sebagai individu yang merupakan komponen pendidikan yang aktif untuk mencapai tujuan pendidikan. Eksistensi dan posisi peserta didik adalah dalam rangka mengembangkan diri sesuai harkat dan martabat manusia (HMM)-nya untuk mencapai tujuan pendidikan. Peserta didik merupakan subjek yang menjadi fokus, arah dan sasaran kegiatan yang dilaksanakan oleh pendidik dalam situasi pendidikan. Selanjutnya, Prayitno (2002) menyebutkan bahwa peserta didik tidak harus berarti manusia kecil atau manusia muda, melainkan manusia dengan berbagai latar belakang usia dan kondisi yang menghendaki memperoleh sesuatu dari hubungannya dengan pendidik. Penjabaran di atas senada dengan pandangan Islam bahwa peserta didik merupakan manusia yang memiliki sejumlah fitrah atau potensi dasar yang masih perlu dikembangkan.

Berdasarkan hal tersebut, hakikat utama seorang peserta didik adalah pribadi yang sedang berkembang berdasarkan potensi yang dimiliki, bertanggung jawab atas pendidikannya, pribadi yang memiliki potensi, 
insan unik, dan memerlukan pembinaan individual dan perlakuan manusiawi. Faktor potensi merupakan modal utama untuk berkembangnya seseorang. Hal ini sesuai dengan konsep Islam bahwa potensi yang dimiliki manusia dikenal dengan istilah fitrah. Sebagai orang yang punya fitrah, mereka memerlukan bimbingan dan pengarahan yang konsisten menuju ke titik optimal.

\section{Pelaksanaan Proses Pembelajaran}

Sejalan dengan isi Undang-Undang No. 14/2005 tentang Guru dan Dosen \& Usman (1996) mengemukakan bahwa pendidik adalah jabatan atau profesi yang memiliki keahlian khusus. Tugas pendidik bukan hanya mengajar, tetapi juga melakukan tugas mendidik. Oleh karena itu, seorang pendidik harus menguasai dasar-dasar dan praktek pendidikan dan berbagai ilmu pengetahuan lainnya yang terkait dengan pembelajaran untuk mengoptimalkan potensi masing-masing anak.

Dalam kerangka ini, Ansyar (2005) mempertegas bahwa pendidikan melibatkan high-touch, dan tidak hanya terfokus pada high-tech semata. Artinya, seorang pendidik dituntut tanggung jawabnya untuk melaksanakan proses pembelajaran tersebut secara profesional, yaitu melaksanakan proses pendidikan yang didasarkan pada kaidah-kaidah keilmuan pendidikan yang sasaran akhirnya adalah pengembangan potensi setiap anak yang optimal. Oleh karena itu, dalam setiap proses pembelajaran pendidik tidak boleh hanya mengisi proses pembelajaran dengan pemompaan materi melalui metode pengajaran (high-tech) saja, namun juga memberdayakan setiap potensi anak sesuai irama dan tempo pembelajaran sesuai dengan potensi dan kebutuhan peserta didik (high-touch).

Berdasarkan uraian di atas terlihat bahwa tugas utama pendidik adalah untuk memfasilitasi perkembangan potensi anak agar peserta didik menjadi insan terdidik. Hal demikian mengindikasikan bahwa pendidik memiliki beberapa tanggungjawab. Sejalan dengan Usman (1996) bahwa pendidik di samping mengajar, memiliki tanggung jawab sebagai pemimpin kelas, fasilitator, pengatur lingkungan belajar, ekspeditor, perencana, supervisor, motivator, dan konselor. Artinya tugas pendidik sebagai tenaga profesional meliputi mendidik, mengajar, melatih, membimbing untuk memfasilitasi pembelajaran peserta didik. Mendidik berarti meneruskan dan mengembangkan nilai-nilai hidup (Hakim, D., 2012). Mengajar berarti meneruskan dan mengembangkan ilmu pengetahuan dan teknologi. Melatih berarti mengembangkan keterampilan-keterampilan pada peserta didik (Usman, 1996).

Selanjutnya Prayitno (2005) dan P3KP (2005) mengungkapkan bahwa pendidikan perlu mengaplikasikan kewibawaan dan kewiyataan. Kewibawaan merupakan unsur-unsur yang menentukan kualitas hubungan antara pendidik dan peserta didik. Sedangkan kewiyataan merupakan unsur-unsur yang menentukan isi hubungan antara keduanya.

Suatu konsep kompetensi pendidik dimuat dalam pasal 42 ayat 1 UU-SPN, bahwa pendidik harus memiliki kualifikasi dan sertifikasi sesuai dengan jenjang kewenangan mengajar, sehat jasmani dan rohani, serta memiliki kemampuan untuk mewujudkan tujuan pendidikan nasional. Adapun selengkapnya telah dimuat dalam pasal 8 UU RI No. 14 tahun 2005 tentang Guru dan Dosen, dan Pasal 28 ayat 1 PP No. 19 Th. 2005 tentang Standar Nasional Pendidikan (PP-SNP) memberikan rumusan tentang kompetensi pendidik, yaitu "pendidik harus memiliki kualifikasi akademik, kompetensi, sertifikat pendidik, sehat jasmani dan rohani, serta memiliki kemampuan untuk mewujudkan tujuan pendidikan nasional". Pasal 28 ayat 1 PP-SNP mengaitkan kualifikasi akademik dan kompetensi yang harus dimiliki seorang pendidik dalam statusnya sebagai agen pembelajaran (learning agent) yang berperan antara lain sebagai fasilitator, motivator, pemacu, dan pemberi inspirasi belajar bagi peserta didik. Oleh sebab itulah, pasal 1 ayat 1 UU No. 14/2005 menyebut guru sebagai pendidik profesional dengan tugas utama mendidik, mengajar, membimbing, mengarahkan, melatih, menilai, dan mengevaluasi peserta didik.

Adapun dalam menjalankan tugas tersebut pendidik harus memiliki kompetensi sebagaimana dituangkan dalam pasal 10 ayat 1 UU No. 14 tahun 2005 tentang Guru dan Dosen dan pasal 28 ayat 3 PP-SNP, yaitu kompetensi pedagogik, kompetensi kepribadian, kompetensi sosial, dan kompetensi profesional. Pertama, dari segi sisi kompetensi pedagogik, seorang pendidik harus mampu mengelola pembelajaran, memahami peserta didik, merancang dan melaksanakan pembelajaran, evaluasi hasil belajar, dan pengem-bangan peserta didik untuk mengaktualisasikan berbagai potensi yang dimilikinya. Kedua, kompetensi kepribadian adalah kemampuan kepribadian yang mantap, stabil, dewasa, arif, dan berwibawa serta menjadi teladan bagi peserta didik, dan berakhlak mulia. Ketiga, kompetensi profesional adalah kemampuan penguasaan materi pelajaran 
yang memungkinkannya membimbing peserta didik. Keempat, kompetensi sosial adalah kemampuan pendidik berkomunikasi dan bergaul secara efektif dengan peserta didik, sesama pendidik, tenaga kependidikan, orangtua/wali, dan masyarakat sekitar.

Pemenuhan dari empat kompetensi tersebut maka pendidik akan dapat melaksanakan sistem dan tujuan pendidikan nasional, yaitu berkembangnya potensi peserta didik agar menjadi manusia yang beriman dan bertakwa kepada Tuhan Yang Maha Esa, berakhlak mulia, sehat, berilmu, cakap, kreatif, mandiri, serta menjadi warga negara yang demokratis dan bertanggung jawab.

\section{SIMPULAN DAN SARAN}

Berdasarkan pandangan di atas, pendidikan dengan semua kegiatan yang dilakukan pada dasarnya merupakan ibadah yang mempersiapkan manusia menjalani kehidupannya, membukakan jalan untuk memperkembangkan kehidupannya mencapai tujuan kehidupannya, yaitu kebahagiaan di dunia dan di akhirat. Selain itu, dari fungsinya, manusia ditugaskan sebagai pemimpin di muka bumi yang mengabdi kepada Allah SWT semata. Berdasarkan hal demikian, pendidikan harus berorientasi pada pengembangan semua potensi manusia seoptimal mungkin agar mampu memikul tanggung jawab sebagai khalifah berdasarkan jiwa pengabdian kepada Allah semata. Hal ini berarti bahwa manusia dalam mengemban misi dan amanat untuk menjadi pemimpin di dunia, mereka harus selalu setia pada hak dan kewajiban kepada Allah SWT.

Adapun dalam kedudukannya sebagai ibadah, pendidikan yang dilakukan hendaklah bermotif ibadah pula, yaitu kekuatan batin yang muncul dalam diri seseorang berupa niat untuk berbuat sesuatu kebaikan bagi kemaslahatan umat dan penuh tanggung jawab untuk mendapatkan keridaan dari Allah (ikhlas) semata. Pendidikan dengan proses pembelajaran sebagai intinya perlu dijadikan sebagai suatu sistem yang teratur dan mengemban misi yang cukup luas, yaitu segala sesuatu yang bertalian dengan perkembangan fisik, kesehatan, keterampilan, pikiran, perasaan, kemauan, sosial sampai kepada masalah kepercayaan atau keimanan. Dalam rangka mencapai hal tersebut yaitu melalui upaya sistem yang kolaboratif dan sistematis melalui tiga jalur pendidikan, yaitu informal, formal, dan nonformal perlu diusahakan terus menerus.

\section{DAFTAR RUJUKAN}

Al-Gazali, Al. (1997). Ihya' Ulum al Din. Kairo, Dar Al-Manar.

Al-Nawawi. (2001). Al-Arba'in al-Nabawiyah. Libanon: Dar Ibnu Hazm.

Asfiati, A. (2014). I'jaz Al-Qur'an In The Views Of Al-Zamakhsyari And Sayyid Quthb Futurologi Pendidikan Islam. Fitrah: Jurnal Kajian Ilmu-ilmu Keislaman, 8(1), 107-116.

Baba, S. H. (1995). Aceh: Pusat Dakwah Islamiyah pada Abad ke 16 dan ke 18. Jurnal Usuluddin, 1, 158-168.

Departemen Agama, R. I. (2005). Al-Quran dan Terjemahan. Indonesia: CV Penerbit J-ART.

Depdikbud. (1999). Kamus Besar Bahasa Indonesia. Jakarta: Balai Pustaka.

Depdiknas. (2004. Pendidikan adalah Ibadah. Jakarta. Depdiknas.

Dimyati dan Mudjiono. (1999). Belajar dan Pembelajaran. Jakarta: Rineka Cipta.

Faizah, L. M. E. (2006). Psikologi Dakwah. Jakarta: Kencana Predana.

Gunawan, I., \& Palupi, A. R. (2016). Taksonomi Bloom-Revisi Ranah Kognitif: Kerangka Landasan untuk Pembelajaran, Pengajaran, dan Penilaian. Premiere Educandum: Jurnal Pendidikan Dasar dan Pembelajaran, 2(02).

Gustina, G. (2016). Nilai-Nilai Pendidikan Dalam Kelompok Sebaya. Ta'dib, 17(1), 46-52.

Hakim, D. (2012). Pengembangan Pendidikan Kewirausahaan Berdasarkan Nilai-Nilai Budaya untuk Membentuk Daya Saing dan Karakter Bangsa. Prosiding Seminas, 1(2).

Hasan Langgulung. (1991). Kreativitas dan Pendidikan Islam. Jakarta: Pustaka Al-Husna.

Indonesia, P. R. (2003). Undang-undang Republik Indonesia Nomor 20 Tahun 2003 tentang Sistem Pendidikan Nasional.

Katsir, I., \& Katsir, T. S. T. I. (1984). Diterjemahkan oleh H. Salim Bahreisy dan Said Bahreisy, Bina Ilmu.

Kenneth, Blanchard. (1992). Manajemen Prilaku Organisasi: Pendayagunaan Sumber Daya Manusia. Terjemahan oleh Agus Dharma. Jakarta: Erlangga.

Langgulung, H. (2001). Islamisasi Pendidikan Dari Perspektif Metodologi. Jurnal Pendidikan Islam, 9(3), 17-32. 
Maarif, M. S. (2003). Manajemen Operasi. Jakarta: Grasindo.

Madsen, K.B. (1961). Theories Of Motivation. Copenhagen: Munksgaard.

Masruri, H. H. (2012). Filsafat Sains Dalam Al-Qur'an: Melacak Kerangka Dasar Integrasi Ilmu Dan Agama. El-Qudwah.

Meria, A. (2012). Pendidikan Islam di era globalisasi dalam membangun karakter bangsa. Al-Ta lim Journal, 19(1), 87-92.

Mohd. Ansyar. (2005). Sekolah Efektif. Padang:Universitas Negeri Padang.

Padmowihardjo, S. (2014). Psikologi Belajar Mengajar.

Peraturan Pemerintah No. 19 Th. 2005 tentang Standar Nasional Pendidikan, Jakarta : Badan Standar Nasional Pendidikan.

Pokja Pengembangan Peta Keilmuan Pendidikan. (2005). Peta Keilmuan Pendidikan. Jakarta : Depdiknas Dikti.

Prayitno \& Erman Amti. (1999). Dasar-Dasar Bimbingan dan Konseling. Jakarta : PT Rineka Cipta

Prayitno. (2002). Hubungan Pendidikan. Jakarta : Direktorat SLTP, Dikdasmen Depdiknas.

Prayitno. (2005). Sosok Keilmuan Ilmu Pendidikan. Padang : FIP Universitas Negeri Padang.

Prayitno. (2009). Dasar Teori dan Praksis Pendidikan. Jakarta: Gramedia.

Raharjo, S. B. (2010). Pendidikan Karakter Sebagai Upaya Menciptakan Akhlak Mulia. Jurnal Pendidikan dan Kebudayaan, 16(3), 229-238.

Rahmawati, R. F. (2016). Kaderisasi Dakwah Melalui Lembaga Pendidikan Islam. Tadbir: Jurnal Manajemen Dakwah, 1(1).

Rochmat, S. (2002). Reformasi Pendidikan Agama Di Era Modern Untukmewujudkan Masyarakat Madani. Jurnal Cakrawala Pendidikan, 3(3).

Sanaky, H. A. (2008). Permasalahan dan Penataan Pendidikan Islam Menuju Pendidikan yang Bermutu. El Tarbawi, 1(1), 83-97.

Setyowati, E. (2009). Pendidikan Budi Pekerti Menjadi Mata Pelajaran di Sekolah. Lembaran Ilmu Kependidikan, 38(2).

Shomad, A. (2004). Selayang Pandang tentang Antropologi Pendidikan Islam. Jurnal Pendidikan Agama Islam, 1(1).

Sudarsana, I. K. (2016). Pemikiran Tokoh Pendidikan Dalam Buku Lifelong Learning: Policies, Practices, And Programs (Perspektif Peningkatan Mutu Pendidikan di Indonesia). Jurnal Penjaminan Mutu, 2(2), 44-53.

Suderadjat. (2004). Implementasi Kerikulum Berbasis Kompetensi (KBK). Bandung: CV. Cipta Cekas Grafika.

Suharjono, M. (2013). Pesantren: Model Pendidikan Bernuansa IMTAQ, IPTEK, dan Karakter. Jurnal Pelopor Pendidikan, 4(1), 41-50.

Suherman, E. (2008). Model Belajar dan Pembelajaran Berorientasi Kompetensi Siswa. Educare, $5(2)$.

Suryabrata, Sumadi. (2002). Psikologi Pendidikan. Jakarta: PT. RajaGra-findo Persada.

Ulich, Robert. (1961). Philosophy of Education. New York. American Book Company

Undang-Undang Guru dan Dosen. UU. RI No. 14 Th. 2005, Jakarta : Sinar Grafika.

Usman, Uzer. (1996). Menjadi Guru Profesional. Bandung: Remaja Rosdakarya.

Utari, R., Madya, W., \& Pusdiklat, K. N. P. K. (2011). Taksonomi Bloom. Jurnal: Pusdiklat KNPK.

UU.Nomor 20 Tahun 2003 Tentang Sistem Pendidikan Nasional, Jakarta : BP. Cipta Jaya.

Wahyuddin, W. (2017). Pendidikan Sepanjang Hayat Menurut Perspektif Islam. Saintifika Islamica, 3(02), 191-208. 